\title{
Normal values for the different classes of venous blood mononuclear cells defined by monoclonal antibodies
}

\author{
LK GOFF,${ }^{*}$ JA HABESHA,${ }^{*}$ ML ROSE, $\dagger$ JA GRACIE $\dagger$ W GREGORY \\ From the *ICRF Medical Oncology Unit, St Bartholomew's Hospital, London, the †Thoracic and Cardiac \\ Surgical Unit, Harefield Hospital, Middlesex, and the $\ddagger$ Research Centre for the Mathematical Modelling of \\ Clinical Trials, University of Warwick, Coventry
}

SUMMARY We present the data obtained from routine quantitation of normal venous blood mononuclear cells using 19 monoclonal antibodies against defined mononuclear cell surface antigens. The results indicate different values for percentage and absolute numbers of Tlymphocytes and of $\mathrm{T}$ lymphocyte subsets depending on the monoclonal antibodies used to quantify these populations. In most instances the total number of identified cells was significantly less than the total number of recovered blood mononuclear cells, which suggests the existence in blood of a null cell population. Evidence is advanced to support previous observations that at least a proportion of this population is of $\mathrm{B}$ cell lineage, expressing cytoplasmic immunoglobulin but lacking other class or lineage specific markers. The value of a diverse monoclonal panel in routine quantitation of peripheral blood mononuclear cells is discussed.

Knowledge of the different classes of cell in venous blood is essential for the diagnosis and investigation of a wide variety of clinical disorders. The availability of monoclonal reagents specific for different classes of lymphoid cells and mononuclear phagocytes has increased the precision with which these cells can be defined in blood and tissue. In laboratories where routine quantitation of lymphocytes in blood forms an essential part of the diagnostic work-for example detection of graft rejection, monitoring blood changes in lymphoma/leukaemia-it is necessary to know the range of normal values of lymphoid cell subsets as a comparative basis for the diagnostic evaluation of patients. Our survey of the published work (Table 1) has shown that this information is not generally available, although in many papers values for $T$ cell subsets are given-for example, in patients with acquired immune deficiency syndrome, ${ }^{20}$ rheumatoid arthritis, ${ }^{21}$ and recipients of renal allografts. ${ }^{22}$ The diurnal variation in circulating lymphoid cell numbers has been reported. ${ }^{23}$

We have measured the normal values of class specific ( $T$ and $B$ lymphocytes, monocytes), subset specific $\left(T_{H}, T_{S}, N K\right.$ cells $)$, and HLA-DR, C-ALLA, and transferrin receptor specific monoclonal antiAccepted for publication 13 September 1984 bodies in 29 samples of venous blood from normal volunteer donors.

\section{Material and methods}

The techniques of cell separation employed were essentially those of Habeshaw and Young. ${ }^{24}$

Samples $(16-20 \mathrm{ml})$ of venous blood were $\delta$ obtained from 29 normal volunteers (19 women and 10 men, mean age 33.8 years) by venepuncture into preservative free heparin $(50 \mathrm{u} / \mathrm{ml})$. Blood was taken between 8.30 and $11.00 \mathrm{am}$.

The total white cell count was determined using a Coulter counter (model ZB1), and the differential o count was determined from May Grunwald-Geimsa N stained smears for each sample.

Blood was diluted $1 / 2$ with tissue culture medium $\sigma$ RPMI 1640, layered on to Ficoll Paque gradients (density 1.076) (Pharmacia Ltd), and centrifuged at $\stackrel{\circ}{\odot}$ $400 \mathrm{~g}$ for $30 \mathrm{~min}$ at $18^{\circ} \mathrm{C}$. The mononuclear cell $\stackrel{\oplus}{?}$ band was totally aspirated and washed twice before $T$ counting. The total numbers of recovered cells were $\overline{0}$ derived from this cell count. Levels of polymor- $\overrightarrow{\mathbb{D}}$ phonuclear cell contamination were within the range $\mathbb{\mathbb { D }}$ described previously $(0.9 \%$ at Ficoll/Triosil interface).$^{24}$ 
Table 1 Monoclonal antibodies used and their described specificities and values

\begin{tabular}{|c|c|c|c|}
\hline Monoclonal antibody & Described specificity & $\begin{array}{l}\text { Normal value for mononuclear cells in } \\
\text { peripheral blood }\end{array}$ & Reference \\
\hline $\begin{array}{l}\text { Leu1/Leu4 (OKT1) } \\
\text { OKT3 (UCHT1) } \\
\text { OKT4 } \\
\text { Leu3a } \\
\text { OKT8 (OKT5) } \\
\text { Leu2a } \\
\text { T11* } \\
\text { B1 } \\
\text { BA1 }\end{array}$ & $\begin{array}{l}\text { Pan T cell } \\
\text { Pan T cell } \\
\text { T helper/inducer } \\
\text { T suppressor/cytotoxic } \\
\text { E rosette receptor } \\
\text { Pan B cell } \\
\text { Most B cells and malignant surface } \\
\text { immunoglobulin positive cells }\end{array}$ & $\begin{array}{l}\text { All T cells } \\
\text { All T cells } \\
55-60 \% \text { T cells } \\
47-78 \% \text { T cells } \\
20 \% \text { T cells } \\
22-46 \% \text { T cells } \\
75 \% \text { peripheral lymphoid cells } \\
9 \pm 2 \% \text { mononuclear cells } \\
\text { Surface immunoglobulin positive } 7.6 \% \text {; } \\
\text { negative } 0.7 \%\end{array}$ & $\begin{array}{l}1,2,3 \\
4,5 \\
4,6 \\
2,3 \\
6 \\
2,3 \\
7 \\
8 \\
9\end{array}$ \\
\hline $\begin{array}{l}\text { BA2 } \\
33 \cdot 1\end{array}$ & $\begin{array}{l}\text { Bone marrow lymphoid progenitor cells } \\
\text { Epstein-Barr virus transformed B cells } \\
\text { Some chronic lymphocytic leukaemia B } \\
\text { lymphocytes }\end{array}$ & $\begin{array}{l}<1 \%(\text { range } 0-2 \%) \text { mononuclear cells } \\
0 \text { or very low }\end{array}$ & $\begin{array}{l}10 \\
11\end{array}$ \\
\hline $\begin{array}{l}\text { J5 } \\
\text { Leu7 } \\
\text { W6/32 } \\
\text { 2D1 } \\
\text { OKT9 } \\
\text { Ca2-II } † \\
\text { OKM1 } \\
\text { MO2 }\end{array}$ & \multicolumn{2}{|c|}{$\begin{array}{ll}\text { Common acute lymphoblastic leukaemia antigen } 0 \text { or very low } \\
\text { NK and K cells } & 15 \cdot 1 \pm 7 \cdot 1 \% \text { peripheral lymphoid cells } \\
\text { Anti-HLA-A, B, C } & \text { All mononuclear cells } \\
\text { Antihuman leucocyte antigen } & \text { All T and B cells, monocytes weakly } \\
\text { Antitransferrin receptor } & 0 \text { or very low } \\
\text { Antimonomorphic HLA-DR } & \text { B cells, monocytes, transformed T cells } \\
\text { Monocytes and null cells } & 27 \% \text { mononuclear cells } \\
\text { Monocytes } & 9 \pm 4 \% \text { mononuclear cells }\end{array}$} & $\begin{array}{l}12 \\
13 \\
14 \\
15 \\
16 \\
17 \\
18 \\
19\end{array}$ \\
\hline
\end{tabular}

*We found the mean normal value for T11 expression to be lower than that given in reference 6.

†Ca2-II normally detects B cells and circulating monocytes but values may be higher if transformed $\mathrm{T}$ cells are present.

\section{MONOCLONAL ANTIBODIES}

The monoclonal antibodies used in this study are shown in Table 1 . The titre for each reagent was determined, and the monoclonal and second phase fluorescein isothiocyanate goat antimouse antibody were used as described by Habeshaw et al. ${ }^{25}$ The percentage of cells showing clear positive fluorescence was determined using a Zeiss photomicroscope IV equipped for phase contrast and incident light ultraviolet fluorescence.

\section{CYTOPLASMIC IMMUNOGLOBULIN}

Cytocentrifuge preparations were air dried, fixed in $95 \%$ ethanol, and then washed twice in phosphate buffered saline. Slides were stained with monoclonal anti-G, M, A, D, K, and $L$ by adding $50 \mu \mathrm{l}$ of appropriate antibody to each preparation and incubating at $4^{\circ} \mathrm{C}$ in a humid atmosphere for $30 \mathrm{~min}$. Slides were washed by immersing in phosphate buffered saline and agitating on a rotating shaker for $1 \mathrm{~h}$. Fifty microlitres of fluorescein isothiocyanate goat antimouse second phase antibody was added to each preparation and incubated in the same way. Slides were washed as before, mounted in Uvinert aqueous mountant (BDH Chemicals), and viewed.

\section{STATISTICAL ANALYSIS}

All $p$ values are based on a paired $t$ test.

\section{Results}

The percentage values and numbers of mononuclear cells reacting with each monoclonal reagent are given in Tables 2 and 3 and illustrated graphically in
Table 2 Percentages of mononuclear cells reacting with described monoclonal antibodies

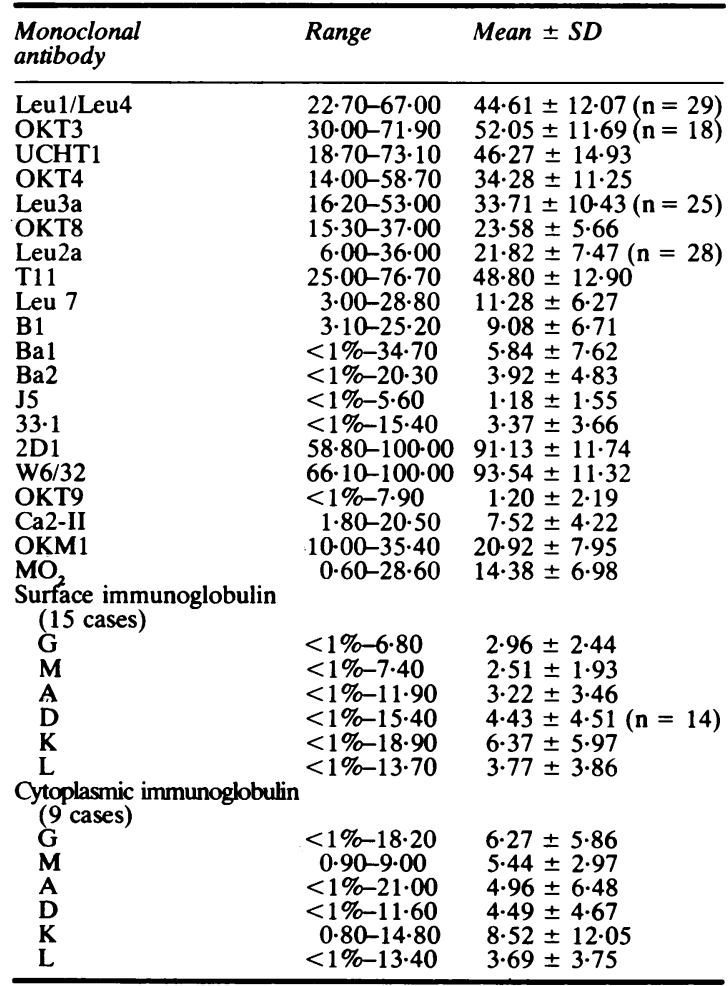

Each carried out on 20 cases except where indicated.

As only 200 cells were counted for each monoclonal antibody the possibility of missed positives cannot be neglected; therefore, where no marked cells were observed, a value of $<1 \%$ is given. 
Table 3 Absolute numbers of mononuclear cells reacting with described monoclonal antibodies $(\times 10 \% \mathrm{ml})$

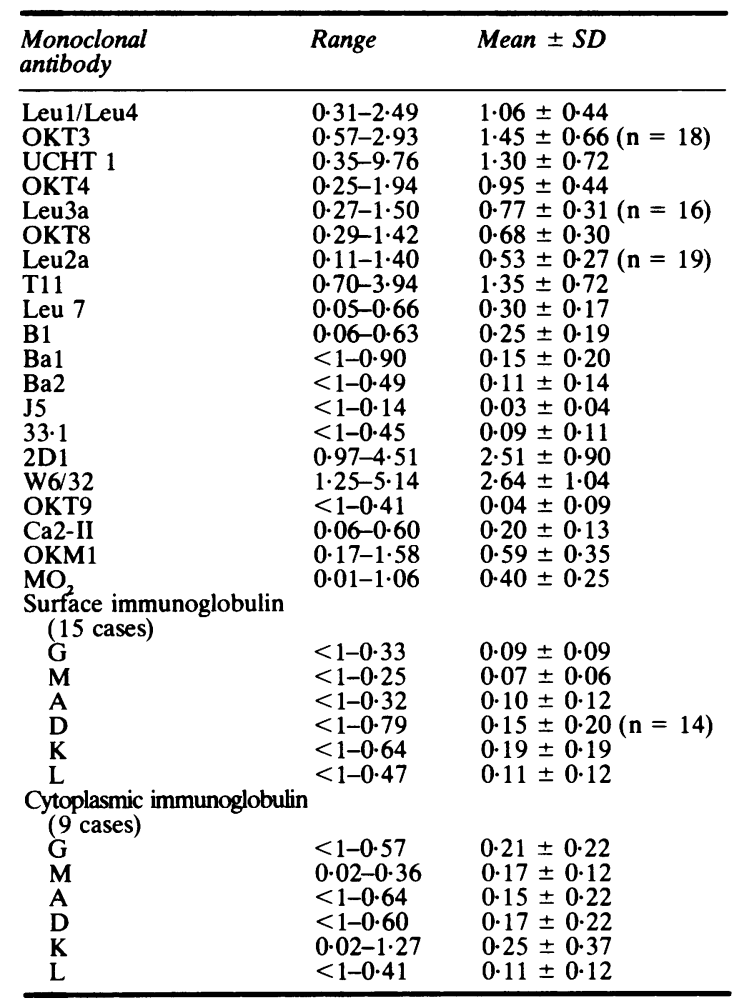

Each carried out on 20 cases except where indicated

the Figure. Treating the markers OKT3/UCHT1 as pan $\mathrm{T}$ cell, $\mathrm{B} 1$ as pan $\mathrm{B}$ cell, $\mathrm{MO}_{2}$ as monocyte specific, and Leu 7 as identifying a separate blood mononuclear cell subset (NK), we have tested the assumption that all mononuclear cells are of these categories - that is, "the defined mononuclear cells" shown in Table 4. A paired $t$ test was used on the difference between the sum of defined mononuclear cell classes and total recovered venous blood mononuclear cell count (from the differential count, recovery, and known blood volume). The significance of this result $(p<0.001)$ indicates the presence of an unmarked cell population. When this test was repeated with values obtained for the antibody 2DI (HLel) (reactive with all haematopoietic mononuclear cells) as "the defined mononuclear cells" similar results were obtained ( $p<00.001)$. Values of cells unaccounted for were tested for correlation with the percentage recovery of mononuclear cells from the Ficoll/Triosil interface. There was no statistical correlation (using Kendall's correlation coefficient) of unmarked cells with recovery. It is therefore probable that a circulating null cell population exists. These cells are not monocytes (determined from $\mathrm{MO}_{2}$ ) but specific tests to exclude pinocytosis of immunoglobulin (which might lead to confusion) were not done. Values obtained for the pan B cell marker B1 and surface immunoglobulin positive cells $(\mathrm{K}+\mathrm{L})$ are concordant across the range. It is apparent that the $K$ to $L$ ratios of surface immunoglobulin positive cells and of cytoplasmic immunoglobulin positive cells are similar. It appears that a proportion of cytoplasmic immunoglobulin positive cells are B1 negative, negative with the markers $\mathrm{Ba} 1$ and $\mathrm{Ba} 2$, and HLA-DR, and correspond to one category of null cells defined statistically in Table 4 . When the category of cytoplasmic immunoglobulin positive $(\mathrm{K}+\mathrm{L})$ cells (distinguished from B1 positive or surface immunoglobulin positive cells) is included in the defined categories of mononuclear cells (for seven donors only in this sample) the null cell component is accounted for. Double staining for cytoplasmic and surface immunoglobulin was not within the scope of this study. Previous reports, such as that of Niaudet et $a l,{ }^{29}$ indicate cytoplasmic immunoglobulin positive cells to be a normal, minor peripheral blood population.

An analysis of total $\mathrm{T}$ cells defined by pan $\mathrm{T}$ cell markers and subset markers Leu3a, Leu2a, and OKT4, OKT8 is presented in Table 5. In 17 of 20 individuals the sum of Leu $3 a+$ Leu2a bearing cells was between $4.7 \%$ and $36.5 \%$ (mean $14.5 \%$ ), which was less than the total $\mathrm{T}$ cells using pan $\mathrm{T}$ cell reagents Leu 1 or Leu4.

In 8 of 12 individuals OKT $4+$ OKT 8 positive T

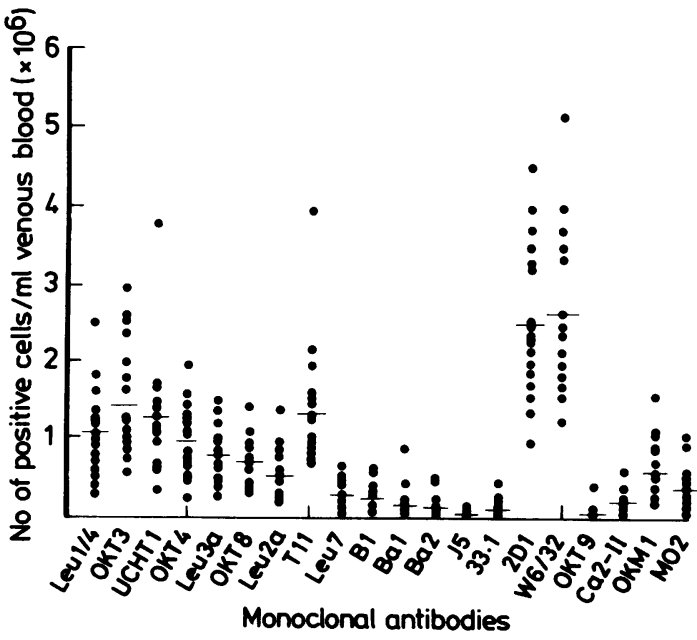

Distribution of cells marking with monoclonal antibodies in normal venous blood (with mean bars). 
Table 4 Total venous blood mononuclear cells (absolute numbers $\times 10 \% \mathrm{ml}$ )

\begin{tabular}{|c|c|c|c|c|c|c|c|c|c|}
\hline Donor & OKT3 & $+B 1$ & + & $\mathrm{MO}_{2}$ & $+\quad$ Leu 7 & $=\begin{array}{l}\text { Sum of defined } \\
\text { mononuclear cell } \\
\text { classes }\end{array}$ & $\begin{array}{l}\text { Total venous blood } \\
\text { mononuclear cells } \\
\text { from count }\end{array}$ & Unmarked cells & $\begin{array}{l}\text { Percentage recovery } \\
\text { ofmononuclear cells } \\
\text { from Ficoll interface }\end{array}$ \\
\hline $\begin{array}{r}1 \\
2 \\
3 \\
4 \\
5 \\
6 \\
7 \\
8 \\
9 \\
10 \\
11 \\
12 \\
13 \\
14 \\
15 \\
16 \\
17 \\
18 \\
19\end{array}$ & $\begin{array}{l}2.58 \\
1.05 \\
2.93 \\
0.78 \\
1.02 \\
0.87 \\
1.64 \\
1.23 \\
1.27 \\
1.11 \\
0.57 \\
1.04 \\
0.99 \\
1.98 \\
2.37 \\
1.26 \\
1.05 \\
1.78 \\
0.95\end{array}$ & $\begin{array}{l}0.57 \\
0.27 \\
0.55 \\
0.06 \\
0.13 \\
0.33 \\
0.61 \\
0.40 \\
0.63 \\
0.14 \\
0.06 \\
0.12 \\
0.11 \\
0.31 \\
0.14 \\
0.16 \\
0.13 \\
0.29 \\
0.06\end{array}$ & & $\begin{array}{l}0.37 \\
0.30 \\
0.95 \\
0.09 \\
0.52 \\
0.39 \\
0.45 \\
0.43 \\
0.42 \\
0.22 \\
0.18 \\
0.53 \\
0.01 \\
0.30 \\
0.60 \\
0.24 \\
0.46 \\
1.06 \\
0.38\end{array}$ & $\begin{array}{l}0.29 \\
0.25 \\
0.54 \\
0.16 \\
0.49 \\
0.44 \\
0.22 \\
0.27 \\
0.30 \\
0.10 \\
0.49 \\
0.10 \\
0.24 \\
0.66 \\
0.13 \\
0.42 \\
0.14 \\
0.29 \\
0.05\end{array}$ & $\begin{array}{l}3.81 \\
1.87 \\
4.97 \\
1.09 \\
2.16 \\
2.03 \\
2.92 \\
2.33 \\
2.62 \\
1.57 \\
1.30 \\
1.79 \\
1.35 \\
3.25 \\
3.24 \\
2.08 \\
1.78 \\
3.42 \\
1.44\end{array}$ & $\begin{array}{l}4.20 \\
3.06 \\
5.10 \\
1.26 \\
3.41 \\
1.97 \\
2.42 \\
2.27 \\
2.87 \\
1.89 \\
1.72 \\
2.48 \\
1.85 \\
4.00 \\
3.40 \\
2.62 \\
2.38 \\
3.76 \\
1.56\end{array}$ & $\begin{array}{r}0.39 \\
1.19 \\
0.13 \\
0.17 \\
1.25 \\
0.06 \\
-0.50 \\
-0.06 \\
0.25 \\
0.32 \\
0.42 \\
0.69 \\
0.50 \\
0.75 \\
0.16 \\
0.54 \\
0.60 \\
0.34 \\
0.12\end{array}$ & $\begin{array}{l}52 \cdot 4 \\
48 \cdot 9 \\
28 \cdot 8 \\
62 \cdot 6 \\
49 \cdot 6 \\
82.0 \\
52.9 \\
60.0 \\
46 \cdot 7 \\
42 \cdot 0 \\
77 \cdot 8 \\
43 \cdot 7 \\
84 \cdot 9 \\
56 \cdot 6 \\
41 \cdot 8 \\
41.0 \\
73.0 \\
25 \cdot 6 \\
64 \cdot 3 \\
=53 \cdot 22 \pm 16.65 \%\end{array}$ \\
\hline
\end{tabular}

cells were from $6.3 \%-21.1 \%$ (mean $10.2 \%$ ), which was greater than the sum of Leu3a + Leu2a positive $T$ cells. In 10 of 12 individuals OKT3 values exceeded Leu 1 or Leu 4 positive cells in the same sample, although these differences are not significant over the whole series. These differences do influence slightly the OKT4 to OKT8 ratio $(1 \cdot 44)$ compared with the Leu3a to Leu2a ratio $(1 \cdot 58)$, which is of clinical importance (in three instances the OKT4 to OKT8 ratio was reversed) but not statistical significance. The same differences were found in our two laboratories independently and are real. We could find no constant association to explain the discrepancy. In individual cases OKT4 appeared to mark more cells than Leu3a, with OKT8 and Leu2a marking similar numbers. Where the discrepancies occur they can result in as much as $10 \%$ error in the estimation of total $\mathrm{T}$ cells from the sum of OKT4/Leu3a + OKT8/Leu2a positive cells.

\section{Discussion}

Monoclonal antibodies reactive with a single epitope may give rise to unexplained and occasionally

Table 5 Pan $T$ and $T$ cell subset marking with $O K T$ and Leu monoclonal antibodies (percentages)

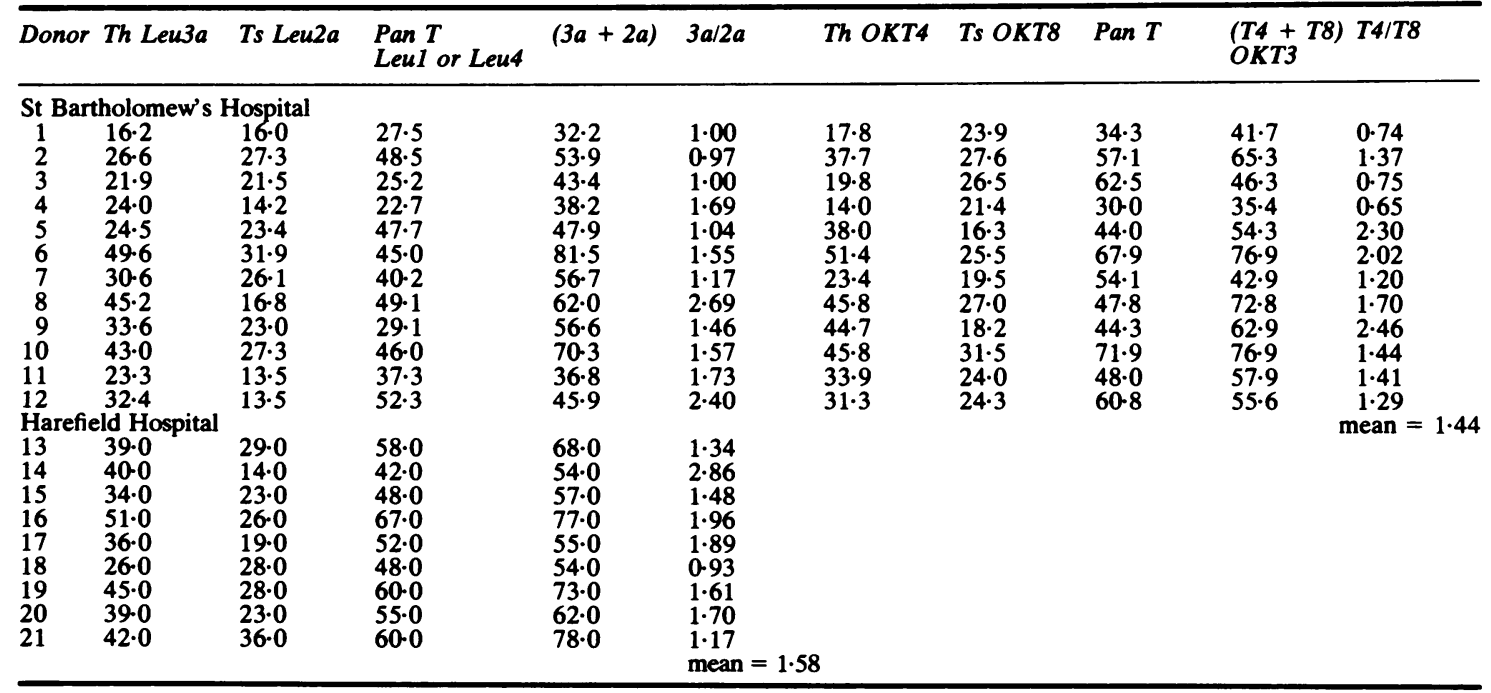


bizarre results. It is therefore of considerable advantage to use several characterised antibodies against a single cell. When dealing with malignancies of the lymphoid system in particular, a single marker is manifestly insufficient to characterise a malignant population. For example, OKT11 may be expressed on cells of leukaemic reticuloendotheliosis, and OKT3 may be reactive with surface immunoglobulin positive cells. ${ }^{2526}$ What concerns the clinical immunologist is the extent to which a given monoclonal antibody operationally defines a given cell lineage or subset. The more sophisticated techniques of co-capping, double fluorescence staining, and functional characterisation of cells are often beyond the reach of the routine laboratory. Some objective evaluation of the currently available monoclonal antibodies in marking routine peripheral blood samples was the purpose of this study.

The markers OKT3/UCHT1, B1, $\mathrm{MO}_{2}$, and Leu 7 have been used here as if they defined the whole of the blood mononuclear cell population in terms of the cell classes T cell, B cell, monocyte, and NK cell. This is a convenience which is not necessarily real. For example, the population of cells defined by the monoclonal Leu 7 may be shown by other criteria to include a proportion of monocytes/macrophages and T cells. ${ }^{27}$ It is thus not strictly accurate to regard the Leu 7 positive cell as belonging to a separate lineage of peripheral blood mononuclear cells, in this paper labelled NK cells. None the less, it is established practice to use markers in this way to define a statistical "average normal" blood mononuclear cell profile. In a similar sense, classes of T cells, B cells, and monocytes may be so defined, and there seems no reason why such data should not form the basis for a comparison of normal and diseased blood.

The normal range of values obtained corresponds well between our two laboratories (Harefield Hospital and St Bartholomew's Hospital). Some markers-for example OKT3 and OKT11-while possessing the same nominal pan $\mathrm{T}$ cell specificity, give different values in some individual samples. Values we have obtained are similar to those found by other means-for example, fluorescence activated cell sorter, ${ }^{23}$ rosetting with chromic chloride coupled antibody coated red cell ${ }^{28}$ Differences in recovery from the initial density gradient do not appear to affect grossly the normal values obtained. This does not exclude, of course, the possibility that storage or the presence of clinically important disease might influence recovery from density gradients of blood mononuclear cells, thus altering the profile.

The lineage markers OKT3, B1, MO 2 , and Leu 7 did not define the entire mononuclear cell population. Evidence is presented that at least a proportion of this null component is of $B$ cell lineage, lacking surface immunoglobulin, the pan B cell markers B1, and the HLA-DR marker but expressing cytoplasmic immunoglobulin. Previous attempts to define this nuil population ${ }^{29}$ would in part support this conclusion. The circulating B cell population is composed of B cells with $M+D$ surface immunoglobulin, B cells with immunoglobulin of other heavy chain classes, and B cells expressing cytoplasmic immunoglobulin only. All surface immunoglobulin positive B cells appear to mark with B1 and fewer with either $\mathrm{Ba} 1$ or $\mathrm{Ba} 2$. C-ALLA positive $(\mathrm{J} 5+)$ cells are rare, but occasionally form a significant percentage-for example $5.6 \%$ (Table 2) of peripheral blood mononuclear cells. The normal percentage of mononuclear cells expressing the transferrin receptor is $1 \%$ or less.

Comparison in individuals of staining with Leu and OKT antisera for T helper and T suppressor subpopulations shows variations in the Th to Ts ratio (Table 5, donors 4, 5, and 12), which may be of clinical importance-for example, reversed $T h$ to $T s$ ratio-if the different staining characteristics of these monoclonal antibodies is not borne in mind.

This study has shown that normal cell populations in blood may be operationally defined. Essentially, more than one class or lineage specific monoclonal antibody is required to give the assurance of internal control. Normal values do vary widely but are sufficiently reproduceable to be of clinical use. We have found that cell recoveries from density gradient interface are generally lower than published values, but this does not appear to have a significant influence on the normal venous blood mononuclear cell profile in the absence of clinically important disease.

\section{References}

' Reinherz EL, Kung PC, Goldstein G, Schlossman SF. A monoclonal antibody with selective reactivity with functionally mature human thymocytes and all peripheral human cells. $J$ Immunology 1979;123:1312-7.

${ }^{2}$ Evans RL, Wall DW, Platsoucas CD, et al. Thymus dependent membrane antigens in man: inhibition of cell mediated lympholysis by monoclonal antibodies to TH2 antigen. Proc Natl Acad Sci 1981;78:544-8.

${ }^{3}$ Ledbetter JA, Evans RL, Lipinski M, Cunningham-Rundles C, Good RA, Herzenberg LA. Evolutionary conservation of surface molecules that distinguish $\mathrm{T}$ lymphocyte helper/inducer and cytotoxic/suppressor subpopulations in mouse and man. $J$ Exp Med 1981;153:310-23.

${ }^{4}$ Kung PC, Goldstein G, Reinherz EL, Schlossman SF. Monoclonal antibodies defining distinctive human $\mathrm{T}$ cell surface antigens. Science 1979; 206:347-9.

${ }^{5}$ Beverley PCL, Callard RE. Distinctive functional characteristics of human " $\mathrm{T}$ " lymphocytes defined by $E$ rosetting or a monoclonal anti-T cell antibody. Eur J Immunol 1981;11:329-34. 
- Reinherz EL, Kung PC, Goldstein G, Schlossman SF. A monoclonal antibody reactive with the human cytotoxic/suppressor $\mathrm{T}$ cell subset previously defined by a heteroantiserum termed TH2. J Immunol 1980;124:1301-7.

' Verbi W, Greaves MF, Schneider C, et al. Monoclonal antibodies OKT11 and OKT11A have pan-T reactivity and block sheep erythrocyte "receptors". Eur J Immunol 1982; 12:81-6.

${ }^{8}$ Stashenko P, Nadler LM, Hardy R, Schlossman SF. Expression of cell surface markers after human $B$ lymphocyte activation. Proc Natl Acad Sci 1981;78:3848-52.

9 Abramson CS, Kersey JH, LeBien TW. A monoclonal antibody (BA-1) reactive with cells of human B lymphocyte lineage. J Immunol 1981;126:83-8.

${ }^{10}$ Kersey JH, LeBien TW, Abramson CS, Newman R, Sutherland R, Greaves M. p24: a human leukaemia-associated and lymphohemopoietic progenitor cell surface structure identified with monoclonal antibody. J Exp Med 1981;153:726-31.

" Marti GE, Kindt TJ. A monoclonal antibody with reactivity for lymphoid cells transformed or activated by EBV. J Cell Biochem 1982;6:39.

${ }^{12}$ Ritz J, Pesando JM, Notis-McConarty J, Lazarus H, Schlossman SF. A monoclonal antibody to human acute lymphoblastic leukaemia antigen. Nature 1980;283:583-5.

${ }^{13}$ Abo T, Balch CM. A differentiation antigen of human NK and $\mathrm{K}$ cells identified by a monoclonal antibody (HNK-1).J Immunol 1981;127:1024-9.

14 Parham P, Barnstable CJ, Bodmer WF. Use of a monoclonal antibody (W6/32) in structural studies of HLA-A, B, C antigens. J Immunol 1979; 123:342-9.

is Beverley PCL, Linch D, Delia D. Isolation of human haematopoietic or progenitor cells using monoclonal antibodies. Nature 1980;287:332-3.

${ }^{16}$ Sutherland R, Delia D, Schneider C, Newman R, Kemshead J, Greaves $M$. Ubiquitous cell surface glycoprotein on tumour cells is proliferation-associated receptor for transferrin. Proc Natl Acad Sci 1981;78:4515-9.

${ }^{17}$ Charron DJ, McDevitt HO. Analysis of HLA-D regionassociated molecules with monoclonal antibody. Proc Natl Acad Sci 1979;76:6567-71.

${ }^{18}$ Breard J, Reinherz EL, Kung PC, Goldstein G, Schlossman SF. A monoclonal antibody reactive with human peripheral blood monocytes. J Immunol 1980; 124:1943-8.
${ }^{14}$ Todd RF III, Nadler LM, Schlossman SF. Antigens on human monocytes identified by monoclonal antibodies. J Immunol 1981;126:1435-42.

${ }^{20}$ Fahey JL, Detels R, Gottlieb M. Immune-cell augmentation (with altered T-subset ratio) is common in healthy homosexual men. (letter). $N$ Engl J Med 1983;308:842.

${ }^{21}$ Veys EM, Hermanns P, Schindler J, Kung PC, Goldstein G, Symoens J, van Wauwe J. Evaluation of T cell subsets with monoclonal antibodies in patients with rheumatoid arthritis. $J$ Rheumatol 1982;9:1.

${ }^{22}$ Cosimi AB, Colvin RB, Burton RC, et al. Use of monoclonal antibodies to $\mathrm{T}$-cell subsets for immunologic monitoring and treatment in recipients of renal allografts. $N$ Engl $J$ Med 1981;305:308-14.

${ }^{23}$ Ritchie AWS, Oswald I, Spedding Micklem H, et al. Circadian variation of lymphocyte subpopulations: a study with monoclonal antibodies. $\mathrm{Br}$ Med J 1983;286:1773-5.

${ }^{24}$ Habeshaw JA, Young GA. Quantitation of subclasses of mononuclear cells in normal human blood membrane receptor studies. Br J Haematol 1975; 29:43-55.

${ }^{25}$ Habeshaw JA, Bailey D, Stansfeld AG, Greaves MF. The cellular content of non-Hodkin lymphomas: a comprehensive analysis using monoclonal antibodies and other surface marker techniques. Br J Cancer 1983;47:327-51.

${ }^{26}$ Aisenberg AC. Current concepts in immunology. Cell surface markers in lymphoproliferative disease. $N$ Engl $\mathrm{J}$ Med 1981;304:331.

${ }^{27}$ Abo T, Cooper M, Balch CM. Characterisation of HNK-1+ (Leu 7) human lymphocytes. I. Two distinct phenotypes of human NK cells with different cytotoxic capability. J Immunol 1982;129:1752-7.

${ }^{28}$ Ling NR, Bishop S, Jefferis R. Use of antibody-coated red cells for the sensitive detection of antigen and in rosette tests for cells bearing surface immunoglobulins. J Immunol Methods 1977; 15:279-89.

${ }^{24}$ Niaudet P, Greaves M, Horwitz D. Phenotypes of "null" lymphoid cells in human blood. Scand J Immunol 1979;9:387-93.

Requests for reprints to: Dr JA Habeshaw, Imperial Cancer Research Fund, Department of Medical Oncology, St Bartholomew's Hospital, West Smithfield, London EC1A 7BE, England. 